\title{
BUB1 wt Allele
}

National Cancer Institute

\section{Source}

National Cancer Institute. BUB1 wt Allele. NCI Thesaurus. Code C49442.

Human BUB1 wild-type allele is located in the vicinity of 2 q14 and is approximately $40 \mathrm{~kb}$ in length. This allele, which encodes mitotic checkpoint serine/threonine-protein kinase BUB1 protein, is involved in the regulation of spindle checkpoints and mitotic integrity. Mutations in this gene, which generate allelic variants have been associated with aneuploidy and several forms of cancer. 